Original Research

\title{
Comparison between Brainstorming and Presentation Teaching-Learning Methods in School of Nursing Rajanpur Punjab Pakistan
}

\author{
Asma Nazir ${ }^{1 *}$ \\ ${ }^{1}$ Gulf College of Nursing DGK, The University of Lahore, Lahore, Pakistan
}

\begin{tabular}{|c|c|}
\hline Article Info & Abstract \\
\hline $\begin{array}{l}\text { Article history: } \\
\text { Received: } \\
13 \text { March } 2021 \\
\text { Accepted: } \\
29 \text { March } 2021\end{array}$ & $\begin{array}{l}\text { Introduction: It is necessary to identify the students' diversities when we } \\
\text { are going to perform our teaching in the classroom, it is also essential } \\
\text { when we prepare our lecture to conduct in the classroom. Teachers used } \\
\text { various methods to teach the students in the classroom. Several earlier } \\
\text { studies are available on the effectiveness of different models of teaching } \\
\text { approaches. This study intended the effect of using brainstorming and }\end{array}$ \\
\hline $\begin{array}{l}\text { Keywords: } \\
\text { brainstorming } \\
\text { method, nursing } \\
\text { instructors, } \\
\text { presentation } \\
\text { method, teaching } \\
\text { strategies }\end{array}$ & $\begin{array}{l}\text { Methods: Exploratory study design was used. } 42 \text { female nursing students } \\
\text { of } 2 \text { nd year class from } 4 \text {-year diploma of general nursing and eight } \\
\text { professional nursing instructors of School of Nursing Rajanpur. } \\
\text { Descriptive statistics were used to identify the effectiveness of elected } \\
\text { (brainstorming \& presentation) teaching-learning strategies. Chi square } \\
\text { was used to compare the academic performance (marks obtained) } \\
\text { between students having different teaching-learning style. } \\
\text { Results: The result showed that mean and standard deviation score for } \\
\text { brainstorming and presentation teaching-learning strategies were } \\
10.16 \pm 1.51 \text { and } 10.97 \pm 1.27 \text {. There is significant difference between group } \\
\text { categories (<.05). } \\
\text { Conclusion: The findings from this study show that presentation teaching- } \\
\text { learning method plays a notable effect on students learning. This study as } \\
\text { well exemplify that different teaching-learning method with advance } \\
\text { technology is more useful than the conventional methods of teaching- } \\
\text { learning. }\end{array}$ \\
\hline
\end{tabular}

${ }^{*}$ Corresponding Author:

e-mail: asmanazir4300@gmail.com

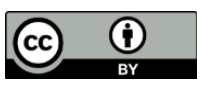

This work is licensed under a Creative Commons Attribution 4.0 International License. 


\section{INTRODUCTION}

It is very important to recognize the students' diversities when we are going to execute our lesson plan in classroom even its also essential when we are preparing our lecture to conduct in classroom. Teachers used different kind of teaching method in classroom for student's learning. Rosenshine and Furst [1] reported that pupils learn best when following characteristics are present: 1) variables in teaching method and materials; 2) Interest; 3) Clarity; 4) Task orientated behaviour; 5) Teachers use of structuring comments; 6) Student's opportunity to learn the material; 7) Multiple level of questioning; 8) Enthusiasm. Several previous studies are available on effectiveness of different type of teaching strategies.

Mogahed [2] revealed asking a question is the most common way to raise topics. Whereas Hashempour, et al. [3] conduct a study to investigate the brainstorming and its sub-categories (question and answer, outlining, listening). In the conclusion of their study, there is no significant relationship between brainstorming and EFL learners. In the rapidly varying era, society highly concerned about educated people. There has been much concerned articulated about the quality of teaching strategies in the education institution. All these cancers lead to the issue of teaching strategies and their usefulness in education institute. According to Carkhuff and Berenson [4], teaching is a chance that assists to others to measure their lives absolutely, which suggest to have a tendency to facilitate to offer to our learners pass though their physical, emotional, intellectual and social growth.

Nursing is a grooming field and students come from different intellectual background and have widespread experiences and talent. Field of nursing now becoming more specialized, Oriented, more technical and has given importance at international level. In oder to cope with more technical and specialized changes, it is much more essential to add more skills and expertise in nursing field. To having all these aspects in mind it is very important to select a teaching method carefully when we are going to teach nursing students in classroom for the attainment of maximum successful result without mental stress.

Teachers use various types of teaching learning strategies in their classroom which included traditional and modern teachinglearning strategies e.g. discussion method, lecture, FGD, presentation, demonstration, brainstorming, inquiry method and question answer method. From these all mentioned method, the study conducted a research work on the comparison of two modern teaching learning methods which are presentation and brainstorming teaching learning strategies by conducting a lecture among 2nd year nursing students of school of nursing Rajanpur. And also going to find out the perception of nursing instructor's regarding teaching-learning method through FGD.

\section{LITERATURE REVIEW}

Mogahed [2] conducted a study and claimed that the problems can not be done by the first notion in mind. mattering to consider several 
solutions for problem-solving. Hence, brainstorming is the best alternative way. In distinguish, San Jose and Galang [5] carried out a study to determine the teaching strategies. Using Focus Group Discussion among the students and teachers. The researcher found that teacher used variety of teaching strategies but reporting emerged to be common. Moreover lecture-discussion was found to be most effective strategy in the learning of literature.

Al-Samarraie and Hurmuzan [6] investigated various Brainstorming techniques to improve productivity by the creativity of the individual. Previous studies conducted to investigate several types of brainstorming, including traditional brainstorming, nominal brainstorming, and electronic brainstorming. The review result exposed that each set type of brainstorming was confirmed supporting in a specific area. In 1953, Osborn [7] popularize Brainstorming by his book. He declared, a novice able to augment creativity and productivity with the assist of Brainstorming. Several rules have to measure through brainstorming sitting:

(1) No ideas criticism

(2) Building on suggested by the others

(3) Accepting strange and wild ideas

(4) Welcoming the massive of ideas.

Gore, et al. [8] reported that a collaborative professional development approach with pedagogy-based to impact the quality of teaching experienced. They clarify a measurable effective impact on teaching quality and morale of the teacher based on supporting teacher learning. Brainstorming helps to direct the new behavior people think and smash the ordinary ways. The spontaneous action to take the notes of ideas for the steps in preparation of writing is called Brainstorming. Several studies confirmed that was helpful, some studies rejected [9].

\section{METHODS}

Research work utilizes an exploratory study design on the effectiveness between presentation and brainstorming teachinglearning method. And to illustrate the perception of nursing instructors regarding teaching method through FGD.

The study conducted after got approval from the University Institution Review Board and a Letter of Permission from Gulf College of Nursing DGK, The University of Lahore. All of the participants got the information of the research, and the researcher guaranteed this study did not impact their study or work evaluation performance. The participants signed the informed consent and there are no withdrawal participants during the study.

Participants who took part in this research work consist of 42 students of 2 nd year nursing class and eight instructors of Nursing School of Rajanpur. All female students are included. Lecture should be done at 2nd year nursing classroom and FGD done at instructor's room. For the comparison between brainstorming and presentation, teaching-learning method lecture should be conducted on elected participants in their classroom that already selected topics. Then, the questionnaire distributed in the class on the elected topics covering all aspects of the topics. A Focused group discussion was done among the 
instructors to evaluate the perception regarding teaching-learning strategies.

Questionnaires were developing to evaluate the effectiveness of in cooperation (brainstorming \& presentation) teachinglearning methods. Validity and reliability checked on the "Brainstorming and Presentation Scale" while reconducting the initial tests employed the Cronbach's alpha internal reliability coefficient of the 25 -item scale was 0.77. (1) Strongly Disagree (2) Disagree, (3) Undecided, (4) Agree, and (5) Strongly Agree are among the 25 items in the study's five-point Likert-scale. A semistructured interview guide constructed for Focus group discussion with instructors to get an understanding of the teaching methods.

All required data collected through questionnaire and FGD from the elected participant. Descriptive and inferential data analysis is done for the result. Descriptive statistics was applied for mean and standard deviation.

\section{RESULTS}

The result revealed in table 1 that the average of age of the second year students is 19 years old. Their family are educated with total $97.6 \%$ and the others not educated. Father occupation included labor 50\%, business $28.6 \%$ and others $21.4 \%$. Most of the student participant came from urban area, namely $76.2 \%$ and the others from rural area $23.8 \%$. The number of the students have other qualifications $11.2 \%$ and the others do not have qualifications $88.8 \%$.

This study examined the two different teaching learning strategies (brainstorming and presentation teaching method) and their influence on educational attainment of 2 nd year nursing students at the school of nursing Rajanpur. One of the research objectives was to find out effectiveness of brainstorming and presentation teaching learning methods. For this, two different topics were selected from the course of 2 nd year nursing students and both methods conducted as planned. The major findings of the study were that in general, the students score higher than the average of educational presentation score inconsiderate of the learning style.

The 2nd objective of the study was to compare between brainstorming and presentation teaching learning strategies. Table 2 shows the comparison between two different teaching-learning strategies. This table result illustrates presentation method have mean 10.97 with 1.27 standard deviation and brainstorming method have mean 10.16 and 1.51 SD with p value 0.102 and marks categories $\mathrm{p}$ value is 0.044 ( $\alpha \leq$ 0.1). This result shows presentation method is more effective then brainstorming.

The 3rd goal of the research work was to discover the nursing instructor's perception regarding teaching learning method. For this a focused group discussion was conducted with eight nursing instructors. Total six questions were asked and concluded that all instructors were knew about new strategies of teaching-learning method and the importance of modern teaching method but they usually used traditional teaching method due to lack of modern method. 
Table 1

Demographic characteristics of the subject

\begin{tabular}{lll}
\hline Variables & & Mean \pm SD, n (\%) \\
\hline Age & & $19.26 \pm 0.76$ \\
\hline \multirow{2}{*}{ Family education } & Uneducated & $1(2.4)$ \\
& Educated & $41(97.6)$ \\
Father occupation & Labor & $21(50)$ \\
& Business & $12(28.6)$ \\
\hline \multirow{2}{*}{ Area } & Other & $9(21.4)$ \\
\hline \multirow{2}{*}{ Other Qualification } & Urban & $32(76.2)$ \\
& Rural & $10(23.8)$ \\
\hline
\end{tabular}

Table 2

Marks comparison between presentation and brainstorming teaching learning methods

\begin{tabular}{lllll}
\hline Variables & & Brainstorming & Presentation & p-value \\
\hline Marks (Mean \pm SD) & & $10.16 \pm 1.51$ & $10.97 \pm 1.27$ & 0.102 \\
\hline \multirow{2}{*}{ Marks categories (\%) } & Low & $1(1.2)$ & 0 & \\
& Hedium & $33(39.3)$ & $24(28.6)$ & 0.044 \\
& High & $8(9.5)$ & $18(21.4)$ & \\
\hline
\end{tabular}

\section{DISCUSSION}

This study evaluated between two methods of teaching style, namely brainstorming and presentation teaching method. This study also explored their influence on educational attainment of 2 nd year nursing students at the school of nursing Rajanpur. The findings of this study showed presentation method better than brainstorming. In line with the result of this study, Fayombo [10] reported students prefer to study in the classroom. Student more likely for visual, auditory and kinesthetic class. Moreover, student prefer multiple modes of learning style [10-12]. Teaching method will give impact to student achievement. The mean score of presentation teaching method were higher than brainstorming. The results also showed, the number of high scores in presentation teaching method were higher than brainstorming. Suitable teaching methods with the student preferences will increase their academic performance and achievement $[8,10,13]$.

The quality of teaching method give influence in the study. This is in accordance with Gore, et al. [8] that showed modern teaching method give significant positive impact to the student. The traditional teaching method were easier than other methods [14]. The teacher will prefer traditional methods because they only need small preparation. If they want use another method, they should have to prepare more 
than usual. Moreover, lack of knowledge from the teacher caused they prefer to use traditional method. Lile and Kelemen [15] revealed modern methods of learning strategy delivers the chance to realize the connection in to transfer information and knowledge [16-18]. Shaukat, et al. [19] also found presentation model significantly improved knowledge and intellectual skills, as follows discussions, internet usage, reading proper and newest journals, and visits concerned teachers [20]. Academic performances improved concerning their class test participation, classroom presence, and marks scored in tests when compared with the traditional methods.

Masino and Niño-Zarazúa [21] have identified three components of change for student achievement and performance. The first factor related to providing components of education systems, education resources as follows materials and humans. The next factor is supply-demand determinants that impact behaviors teachers, students, and households. The third factor is participatory and community involvement of school system management strategies. The human resources specifically the teacher is the important factors to impact the second factors [22, 23]. Behaviors among teachers and students will improve if they can adapt the modern teaching method. They will complicate each other between teachers and students.

\section{CONCLUSION}

The finding of this study is in the favor of presentation teaching-learning strategies rather than brainstorming. Previous many studies prove that brainstorming is an effective teaching-learning method. But researcher's study findings illustrate that presentation method is more effective as compare to brain-storming method.

The findings of focused group discussion illustrate that instructors of school of nursing knows about various teaching-learning strategies but use traditional method of teaching-learning without integration of advance technology. Teaching is a mean of offering a unique, definite, and essential social service. Teacher can do it and fulfill the requirements of effective teaching and can get highest academic result by utilizing various modern teaching-learning methods with integration of advance technology.

Teachers should use modern teachinglearning method in class room based on the constructive learning theory. In addition, ensure integration of advance technology e.g. audio-visual aid, multimedia. If there is no availability of technology, traditional method is used with innovation in classroom.

\section{ACKNOWLEDGMENTS}

We are very grateful to the teachers of nursing department, Gulf College of Nursing DGK, The University of Lahore, Pakistan.

\section{REFERENCES}

[1] B. Rosenshine and N. Furst, "Research on teacher performance criteria," Research in teacher education, pp. 37-72, 1971.

[2] M. M. Mogahed, "Planning out prewriting activities," International Journal 
of English and Literature, vol. 4, no. 3, pp. 60-68, 2013.

[3] Z. Hashempour, M. Rostampour, and F. Behjat, "The effect of brainstorming as a pre-writing strategy on EFL advanced learners' writing ability," Journal of Applied Linguistics and Language Research, vol. 2, no. 1, pp. 86-99, 2015.

[4] R. R. Carkhuff and D. H. Berenson, The skilled teacher: A systems approach to teaching skills. Human Resource Development Pr, 1981.

[5] A. E. San Jose and J. G. Galang, "Teaching strategies in teaching literature: Students in focus," International Journal of Education and Research, vol. 3, no. 4, pp. 41-50, 2015.

[6] H. Al-Samarraie and S. Hurmuzan, "A review of brainstorming techniques in higher education," Thinking Skills and Creativity, vol. 27, pp. 78-91, 2018.

[7] A. F. Osborn, Applied imagination; principles and procedures of creative problem-solving: principles and procedures of creative problem-solving. Scribner, 1963.

[8] J. Gore, A. Lloyd, M. Smith, J. Bowe, H. Ellis, and D. Lubans, "Effects of professional development on the quality of teaching: Results from a randomised controlled trial of Quality Teaching Rounds," Teaching and teacher education, vol. 68, pp. 99-113, 2017.

[9] M. E. Ledbetter, The Writing Teacher's Activity-a-Day: 180 Reproducible Prompts and Quick-Writes for the Secondary Classroom. John Wiley and
Sons, 2009.

[10] G. Fayombo, "Learning styles, teaching strategies and academic achievement among some psychology undergraduates in Barbados," Caribbean Educational Research Journal, vol. 3, no. 2, pp. 46-61, 2015.

[11] Y. Aungsuroch and J. Gunawan, "Viewpoint: Nurses Preparation in the Era of the Fourth Industrial Revolution," Belitung Nursing Journal, vol. 5, no. 1, pp. 1-2, 2019, doi: 10.33546/bnj.744.

[12] D. K. Uligraff, "Utilizing Poetry to Enhance Student Nurses' Reflective Skills: A Literature Review," Belitung Nursing Journal, 2019, doi: 10.33546/bnj.631.

[13] J. Hackathorn, E. D. Solomon, K. L. Blankmeyer, R. E. Tennial, and A. M. Garczynski, "Learning by Doing: An Empirical Study of Active Teaching Techniques," Journal of Effective Teaching, vol. 11, no. 2, pp. 40-54, 2011.

[14] R. Holubová, "Improving the quality of teaching by modern teaching methods," Problems of Education in the 21st Century, vol. 25, p. 58, 2010.

[15] R. Lile and G. Kelemen, "Results of researches on strategies of teaching/learning/sssessment based on interactive learning methods," ProcediaSocial and Behavioral Sciences, vol. 163, pp. 120-124, 2014.

[16] I. Nofalia and S. A. Wibowo, "Mobile or Web-Based Intervention for Smoking Cessation," Babali Nursing Research, vol. 1, no. 1, pp. 31-38, 2020, doi: 
10.37363/bnr.2020.114.

[17] V. Rodessa, A. Kurniadi, and A. Bandur, "The Impact of Preceptorship Program on Turnover Intention of Fresh Graduate Nurses in Hospital," Babali Nursing Research, vol. 1, no. 3, pp. 131148 , 2020 , doi: 10.37363/bnr.2020.1334.

[18] I. G. Juanamasta, "Pemodelan Konsep Diri Profesional Perawat Terhadap Produktifitas Kerja Perawat Pelaksana di Ruang Rawat Inap," Master, Universitas Airlangga, Surabaya, 2018.

[19] A. Shaukat, T. M. Arain, M. F. Alam, and A. M. Shahid, "Teaching strategies and academic performances of undergraduates in quaid-I-azam medical college, bahawalpur," Journal of the College of Physicians and Surgeons-Pakistan: JCPSP, vol. 17, no. 10, pp. 598602, 2007.

[20] N. M. N. Wati, I. G. Juanamasta, P. L. Linasari, and P. Darmika, "Anxiety Level Responses Of Nursing Students Who
Will Take Competency Tests In Wira Medika Institute Of Health Sciences," Jurnal Keperawatan Respati Yogyakarta, vol. 7, no. 1, pp. 11-15, 2020, doi: 10.35842/jkry.v7i1.389.

[21] S. Masino and M. Niño-Zarazúa, "What works to improve the quality of student learning in developing countries?," International Journal of Educational Development, vol. 48, pp. 53-65, 2016.

[22] K. Kusnanto, I. G. Juanamasta, S. R. Yuwono, Y. Arif, K. A. Erika, and H. Arifin, "Professional Self-Concept Model on Working Productivity of Clinical Nurses," Journal of Global Pharma Technology, vol. 12, no. 9, p. 13, 2020.

[23] I. G. Juanamasta, K. Kusnanto, and S. R. Yuwono, "Improving Nurse Productivity Through Professionalism Self-Concept," in Proceedings of the 9th International Nursing Conference - INC, Airlangga University, Surabaya, 2018: Scitepress, pp. 116-120, doi: 10.5220/0008321401160120. 